\title{
多重せん断機構の概念に基づく有限変形を 考慮した弾性体構成式の提案
}

\author{
上田＼cjkstart恭平1・井合 進2 \\ 1正会員 博士（工学） 京都大学助教 防災研究所（干611-0011 京都府宇治市五ヶ庄） \\ E-mail: ueda.kyohei.2v@kyoto-u.ac.jp \\ 2正会員 工博 京都大学教授 防災研究所（干611-0011 京都府宇治市五ヶ庄）
}

\begin{abstract}
本稿では, 元来は砂の力学モデルとして提案されたひずみ空間多重せん断モデルを参考に, 多重せん断 機構の概念に基づく有限変形を考慮した新たな弾性体構成式を提案した。 提案モデルでは, 多重せん断機 構を構成する仮想的な各単純せん断機構（仮想単純せん断応力と仮想単純せん断ひずみの関係）に対して， 線形もしくはひずみ軟化を考慮した非線形関係を与えている。また， 大変形現象に伴う幾何学的非線形性 を考慮できるよう, 有限変形理論における物質表示と空間表示の双方による定式化がなされている. 提案 モデルの妥当性を検証するため，ゴム材料の引張試験（単純せん断および純せん断）を対象にシミュレー ションを行ったところ，モデルパラメータとしてせん断弾性係数と仮想単純せん断機構におけるせん断強 度（もしくは参照ひずみ）の2つを適切に調整することで, 試験結果を概ね再現できることがわかった.
\end{abstract}

Key Words : elastic body, multiple shear mechanism, finite strain theory, rubber elasticity

\section{1. はじめに}

土木工学の分野において取り扱う対象は，河川，道路， 港湾・空港，鉄道などがその代表的なものであり，これ らはトンネル，橋梁，盛土などの種々の構造物から構成 されている.それらの中でも特に重要度の高い構造物を 設計する際には，施工中はもちろんのこと，当該構造物 がその供用期間にわたって必要とされる性能を維持し続 けることができるかどうか，詳細に検討を行う必要があ る. 性能規定型の詳細設計においては, まず, コンクリ 一トや鉄，地盤など，構造物を構成する各材料の特性を 適切にモデル化することが求められる，その上で，供用 期間中に構造物に作用寸る種々の荷重を考慮し, 要求性 能を満足するかどうか確かめる必要がある。このような 設計を行う場合，荷重を適切に設定することに加え，構 造材料の挙動を精度良くモデル化することが非常に重要 な意味を持つと考えられる.

構造材料のモデル化は, 種々の荷重に伴い材料内部に 発生する応力とひずみの関係を, 数式の形で適切に表現 することにより達成される．この応力〜ひずみ関係は構 成関係（構成モデル）と呼ばれており，ある荷重を受け た際にその材料がどのような挙動を示寸かを規定するも のである. そして，その関係を数式表現したものが構成 式と呼ばれる. 構成式には, 対象とする構造材料に依ら
ず共通する考え方も多く見られるが，基本的には材料ご とに異なる構成式がこれまでに数多く提案されている. 例えば，砂のような地盤材料は，一般に小さいひずみ領 域から（材料的な）非線形性を示すことが知られており 1)，その応力〜ひずみ関係のモデル化として，これまで 種々の構成式が提案されている例社, 2) 4 .

このような種々の材料に対する構成式の中で, 最もシ ンプルなものは弾性体の構成式であろう。土木分野にお いては，例えば，深部の洪積層を構成する地盤材料や岩 盤材料では非線形性が顕著ではないことから，弾性体の うち，特に線形弾性体としてモデル化することがある. また，地盤・構造物系の応答評価を数值解析により行う 場合, 例えば港湾構造物におけるケーソン式岸壁等でも, 線形弾性体がそのモデル化に用いられることが多い5. 土木分野の他に目を向ければ，例えばゴム材料の挙動は 非常にひずみレベルが大きいものの，材料的には弾性で あることから，これまでに様々な非線形弾性体モデルが 提案されているのわ. しかしながら, パラメータの数と 同定精度の間にはトレードオフの関係があるため, 万能 なモデルの提案には至っていないのが実情のようである 》。なお，先に土木分野の他と書いたが，免震ゴムの挙 動に関する研究等は，土木・建築分野でも盛んに行われ ていることを付記しておく.

本論文では，元来は地盤材料の構成式として著者らに 
より提案・改良されてきた砂の力学モデルとしてのひず み空間多重せん断モデル33,4)準じて，まず，多重せん 断機構の概念に基づいて既存の線形弾性体の構成式を再 考する. さらに, 有限変形理論の枠組みに拡張されたひ ずみ空間多重せん断モデル8,99を基にして，多重せん断 機構の概念に基づく有限変形を考慮した新たな非線形弾 性体の構成式を提案する．以下では，その定式化につい て述べるとともに，大変形領域まで含めたゴム材料の引 張試験（単純せん断および純せん断）に対するシミュレ ーション結果についても併せて示す，なお，本論文では 等方性弹性体のみを対象とし，異方性を有する弾性体例 え赫のについては取り扱わないこととする.

\section{2. 多重せん断機構の概念に基づく線形弾性体}

本章では，新たな非線形弾性体の提案に先立ち，従来 から広く用いられている線形弾性体の構成式を, 多重せ ん断機構の概念に基づいて再解釈寸る. なお，本章での 議論はすべて微小変形理論に基づくものとし, 有限変形 理論に基づく非線形弾性体への拡張については, 次章に おいて詳述する.

\section{（1）平面ひずみ条件における線形弾性体の構成式}

等方性線形弾性体の構成式は，3次元空間においては 以下のように表される例えば, 10)。

$$
\begin{gathered}
\left\{\begin{array}{l}
\sigma_{11} \\
\sigma_{22} \\
\sigma_{33} \\
\sigma_{12} \\
\sigma_{23} \\
\sigma_{31}
\end{array}\right\}=\left[\begin{array}{cccccc}
D_{11} & D_{12} & D_{13} & 0 & 0 & 0 \\
D_{12} & D_{22} & D_{23} & 0 & 0 & 0 \\
D_{13} & D_{23} & D_{33} & 0 & 0 & 0 \\
0 & 0 & 0 & D_{44} & 0 & 0 \\
0 & 0 & 0 & 0 & D_{55} & 0 \\
0 & 0 & 0 & 0 & 0 & D_{66}
\end{array}\right] \\
D_{11}=D_{22}=D_{33}=\frac{E(1-v)}{(1+v)(1-2 v)} \\
D_{12}=D_{13}=D_{23}=\frac{E v}{(1+v)(1-2 v)} \\
D_{44}=D_{55}=D_{66}=\frac{E}{2(1+v)}=G
\end{gathered}
$$

ここに, $E$ : ヤング率, $G$ : せん断弾性係数, $v$ : ポ アソン比である.

ここで，問題を簡略化するために，これ以降は2次元 平面ひずみ状態を考えることとする. 式(1)に示す3次元 のひずみ成分のうち，ある一つの方向に関係するひずみ
成分（ここでは， $\left.\varepsilon_{33}, \gamma_{13}, \gamma_{23}\right)$ をすべてゼロとすると， 平面ひずみ条件における応力〜ひずみの関係式は次式の ように求められる.

$$
\hat{\boldsymbol{\sigma}}=\mathbf{D} \hat{\boldsymbol{\varepsilon}}
$$

ここに

$$
\begin{gathered}
\hat{\boldsymbol{\sigma}}^{\mathrm{T}}=\left(\begin{array}{lll}
\sigma_{11} & \sigma_{22} & \sigma_{12}
\end{array}\right) \\
\hat{\boldsymbol{\varepsilon}}^{\mathrm{T}}=\left(\begin{array}{lll}
\varepsilon_{11} & \varepsilon_{22} & 2 \varepsilon_{12}
\end{array}\right) \\
\mathbf{D}=\frac{E}{(1+v)(1-2 v)}\left[\begin{array}{ccc}
1-v & v & 0 \\
v & 1-v & 0 \\
0 & 0 & \frac{1-2 v}{2}
\end{array}\right]
\end{gathered}
$$

ここで, 式(8)の岡性マトリクスを体積変化成分と等 体積変化成分（せん断変形成分）とに分解寸ると,

$$
\mathbf{D}=K\left[\begin{array}{lll}
1 & 1 & 0 \\
1 & 1 & 0 \\
0 & 0 & 0
\end{array}\right]+G\left[\begin{array}{ccc}
1 & -1 & 0 \\
-1 & 1 & 0 \\
0 & 0 & 1
\end{array}\right]
$$

となる，ここに， $K$ は体積弾性係数であり，ヤング率 およびポアソン比との間に以下の関係がある.

$$
K=\frac{E}{2(1+v)(1-2 v)}
$$

\section{（2）多重せん断機構の概念に基づく解釈}

2次元平面ひずみ状態における線形弾性体の剛性マ卜 リクスは，式(9)のように体積弾性係数とせん断弾性係 数により与えられるわけであるが，ここで式(9)は以下 のように書き換えることができる.

$$
\mathbf{D}=K \hat{\mathbf{n}}^{(0)} \otimes \hat{\mathbf{n}}^{(0)}+G \sum_{i=1}^{2} \hat{\mathbf{n}}^{(i)} \otimes \hat{\mathbf{n}}^{(i)}
$$

ここに,

$$
\hat{\mathbf{n}}^{(0) \mathrm{T}}=\left(\begin{array}{lll}
1 & 1 & 0
\end{array}\right)
$$

$$
\hat{\mathbf{n}}^{(1) \mathrm{T}}=\left(\begin{array}{lll}
1 & -1 & 0
\end{array}\right), \hat{\mathbf{n}}^{(2) \mathrm{T}}=\left(\begin{array}{lll}
0 & 0 & 1
\end{array}\right)
$$

したがって，式(5)および式(11)より，2次元平面ひずみ 条件下での線形弾性体の応力〜ひずみ関係は, 以下のと おり書くことができる.

$$
\hat{\boldsymbol{\sigma}}=\mathbf{D} \hat{\boldsymbol{\varepsilon}}=-p \hat{\mathbf{n}}^{(0)}+\sum_{i=1}^{2} q^{(i)} \hat{\mathbf{n}}^{(i)}
$$

ここに，

$$
\begin{gathered}
p=-K \hat{\mathbf{n}}^{(0) \mathrm{T}} \hat{\boldsymbol{\varepsilon}} \\
q^{(i)}=G \hat{\mathbf{n}}^{(i) \mathrm{T}} \hat{\boldsymbol{\varepsilon}} \quad(\text { for } i=1,2)
\end{gathered}
$$


さて，ここで，地盤材料の構成式として提案されてい る砂の力学モデルとしてのひずみ空間多重せん断モデル 3)4ににつて考えることとする．なお，本稿ではあくま で1相系としての非線形弾性体を対象とするため, 応力 テンソルとしては，土質力学における間隙水の影響を考 慮した有効応力ではなく, 常に全応力を用いることとす る. また，間隙水を有する地盤材料の場合には，粒状体 特有のダイレイタンシの影響によりせん断時において等 方圧力（後述の式(17)における $p$ ）が変化する收が，この 影響については考慮しない.

ひずみ空間多重せん断モデルの基本形（テンソル形 式）は，付録1の式(77)により与えられるが，これをべク トル・マトリクス形式に書き換え，さらに積分を離散化 して和記号で表すと, 次式が得られる.

$$
\hat{\boldsymbol{\sigma}}=\mathbf{D} \hat{\boldsymbol{\varepsilon}}=-p \hat{\mathbf{n}}^{(0)}+\sum_{i=1}^{I} q^{(i)} \hat{\mathbf{n}}^{(i)} \Delta \omega
$$

ここに,

$$
\begin{gathered}
\hat{\mathbf{n}}^{(i)}=\left(\begin{array}{ccc}
\cos \omega_{i} & -\cos \omega_{i} & \sin \omega_{i}
\end{array}\right)^{\mathrm{T}} \quad(\text { for } i=1, \ldots, I) \\
\omega_{i}=(i-1) \Delta \omega, \Delta \omega=\pi / I
\end{gathered}
$$

であり， $\hat{\mathbf{n}}^{(0)}$ は式(12)により与えられる。積分を用いた 式(77)では, $\omega=0 \sim \pi$, 寸なわち $\theta=0 \sim \pi / 2$ (付図-1 参照）の範囲における粒子接触力を合算（平均化）する ことで，巨視的な応力テンソルの偏差成分を定義してい る. 一方，式(17)では，積分ではなく和記号を用いてい るため，本来は無数にある接触方向（付図-1における粒 子中心を結ぶ枝方向）を有限個の方向で代表させる必要 がある.ここでは， $\omega=0 \sim \pi$ を $\Delta \omega$ の間隔に分割し, その分割数（すなわち，多重せん断機構を構成する仮想 的な単純せん断機構の数）をI としている. また，同式 における $q^{(i)}$ は仮想単純せん断応力と呼ばれ，付録1の 式(79)と同様に，仮想単純せん断ひずみ $\gamma^{(i)}$ を用いて以 下のように与えられる.

$$
q^{(i)}\left(\gamma^{(i)}\right)=\frac{\gamma^{(i)} / \gamma_{\mathrm{v}}}{1+\left|\gamma^{(i)} / \gamma_{\mathrm{v}}\right|} q_{\mathrm{v}}
$$

ここに， $\gamma^{(i)}$ は式(80)に準じて，巨視的なひずみべクト ル $\hat{\varepsilon}$ を用いて以下のように与えられる。

$$
\gamma^{(i)}=\hat{\mathbf{n}}^{(i) \mathrm{T}} \hat{\boldsymbol{\varepsilon}}
$$

ここで，式(20)を $\gamma^{(i)}$ で微分すると，

$$
\mathrm{d} q^{(i)}=\frac{1}{\left(1+\left|\gamma^{(i)} / \gamma_{\mathrm{v}}\right|\right)^{2}} \frac{q_{\mathrm{v}}}{\gamma_{\mathrm{v}}} \mathrm{d} \gamma^{(i)}=G_{\mathrm{L} / \mathrm{U}}^{(i)} \mathrm{d} \gamma^{(i)}
$$

となり, せん断剛性 $G_{\mathrm{LU}}^{(i)}$ をばね定数のイメージで捉え ると，ひずみ空間多重せん断モデルは仮想的なせん断応
力（増分）とせん断ひずみ（増分）により構成される一 種のばねモデルであるとみなすことが可能である. した がって，先に述べた式(17)における $I$ は，仮想的なばね モデルにおけるばね本数として解釈寸ることができる.

ここで，線形弾性体の構成式（式(14)）とひずみ空間 多重せん断モデル（式(17)）を比較してみる.まず, 式 (17)の右辺第1項に着目寸る. ダイレイタンシの影響を無 視すると, 等方圧力 $p$ の増分は, 体積剛性 $K_{\mathrm{L} / \mathrm{U}}$ と体積 ひずみ増分 $\mathrm{d} \varepsilon$ を用いて以下のとおり書ける.

$$
\mathrm{d} p=-K_{\mathrm{L} / \mathrm{U}} \mathrm{d} \varepsilon
$$

さらに, 体積剛性が定数であると仮定し, 等方圧力 $p=0$ の下で体積ひずみが $\varepsilon=0$ とすると,

$$
p=-K \varepsilon=-K \hat{\mathbf{n}}^{(0) \mathrm{T}} \hat{\boldsymbol{\varepsilon}}
$$

のように書ける.これは，式(15)と等価である.

次に, 式(17)の右辺第2項に着目する. まず，仮想的な ばね本数を $I=2$ とおいた場合, 式(18)は式(13)と等価で あることが確認できる.さらに，式(22)においてせん断 剛性 $G_{\mathrm{L} / \mathrm{U}}^{(i)}$ が応力状態に依らず一定であるとし, 初期条 件として仮想単純せん断応力 $q^{(i)}$ がゼロのときに $\gamma^{(i)}=0$ であるとすると，

$$
q^{(i)}=G \gamma^{(i)}=G \hat{\mathbf{n}}^{(i) \mathrm{T}} \hat{\boldsymbol{\varepsilon}}
$$

となり，これは式(16)と等しくなることがわかる.

以上より，2次元平面ひずみ状態における線形弹性体 の構成式（式(5)および式(14)）は，砂のような粒状体の 構成式としてのひずみ空間多重せん断モデルにおいて, ダイレイタンシの影響を無視し，体積岡性とせん断岡性 が定数で与えられ，かつ仮想的なばね本数を 2 本とした 場合の構成式に相当することが示された.

\section{3. 有限変形理論に基づく非線形弾性体への拡張}

\section{（1）一般的な線形弾性体の構成関係の拡張}

本章では，微小変形理論に基づく2次元平面ひずみ状 態での線形弾性体の構成式を, 幾何学的な非線形性を考 慮できるよう, 有限変形理論の枠組みに拡張する. 有限 変形理論には基準配置に基づく物質表示と, 現配置に基 づく空間表示の 2 種類がある ${ }^{11)}$. また, 有限変形理論で は，各々の表示において種々のひずみテンソル（例えば, Hencky，Biot等）を定義できる，構成式にどのひずみテ ンソルを用いるかは任意性があるものの, 重要なのは work conjugateとなる応力とひずみ (速度) テンソルのペ アを採用することである ${ }^{11)}$. 本論文では, work conjugate となるペアとして, 物質表示では第2Piola-Kirchhofft心力 と Green-Lagrangeひずみを, 空間表示ではCauchy応力と Euler-Almansiひずみを用いることとする. 
まず，有限変形理論における最も単純な非線形弾性体 の構成式として思い付くのは，物質表示もしくは空間表 示による応力とひずみの間に，式(5)と同様の関係をそ のまま適用するモデルである，すなわち，物質表示では，

$$
\hat{\mathbf{S}}=\mathbf{D} \hat{\mathbf{E}}
$$

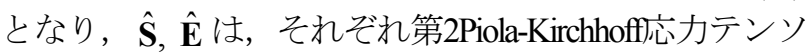
ルおよびGreen-Lagrangeひずみテンソルを，応力・ひずみ の対称性からベクトル形式で表したものである.

一方，空間表示においては，式(9)の剛性マトリクス とEuler-Almansiひずみベクトル $\hat{\mathbf{e}}$ を用いて，Cauchy応力 ベクトル $\hat{\boldsymbol{\sigma}}$ が以下のように与えられる.

$$
\hat{\boldsymbol{\sigma}}=\mathbf{D e \hat { e }}
$$

なお，物質表示における式(26)の関係は，一般にSaintVenant Kirchhoffモデルと呼ばれており，大回転を伴う大 変形・微小ひずタ現象には適用できるものの，大ひずみ を伴う現象には不向きであるとされている11).これにつ いては，4. (1)節において一軸圧縮引張試験のシミュレ ーション結果を後程示すが，変位〜荷重関係において, 変形の進展とともに式(26)(27)が両極端な傾向を示すこと が確認できる.

\section{（2）多重せん断機構の概念に基づく非線形弾性体（物 質表示)}

2. (2)節において，2次元平面ひずみ状態における線形 弾性体の構成式は, 砂の力学モデルとしてのひずみ空間 多重せん断モデルを簡略化したものであることが示され た.このことから，本節と次節では，多重せん断機構の 概念に基づく線形弾性体を拡張し, 新たな非線形弾性体 の構成式を提案する.

まず本節では，物質表示による非線形弾性体の構成式 の導出を行う. 付録1に示寸ように, 元々は微小変形理 論の枠組みで定式化されていたひずみ空間多重せん断モ デルは，大変形領域での精度向上のため，有限変形理論

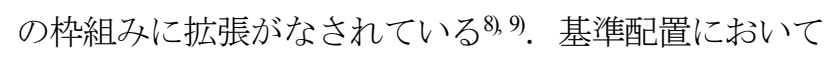
は，物質表示によるひずみ空間多重せん断モデルの基本 形が，式(84)を参考にして以下のように与えられる.

$$
\mathbf{S}=-J p \mathbf{C}^{-1}+\sum_{i=1}^{I} q^{(i)}\left(\left\langle\mathbf{T}^{(i)} \otimes \mathbf{N}^{(i)}\right\rangle-\gamma^{(i)} \mathbf{C}^{-1}\right) \Delta \omega
$$

ここに，本稿では弾性体を対象とするため，土質力学に おける有効応力と全応力の区別をなくすとともに，式 (84)における積分を和記号で置き換えている．なお，テ ンソル形式で表された式(28)をべクトル・マトリクス形 式に書き換えると，以下のようになる.

$$
\hat{\mathbf{S}}=-J p \hat{\mathbf{C}}^{-1}+\sum_{i=1}^{I} q^{(i)}\left(\hat{\mathbf{N}}^{(i)}-\gamma^{(i)} \hat{\mathbf{C}}^{-1}\right) \Delta \omega
$$

ここに

$$
\hat{\mathbf{S}}^{\mathrm{T}}=\left(\begin{array}{lll}
S_{11} & S_{22} & S_{12}
\end{array}\right)
$$

$$
\begin{gathered}
\left(\hat{\mathbf{C}}^{-1}\right)^{\mathrm{T}}=\left(\begin{array}{lll}
C_{11}^{-1} & C_{22}^{-1} & C_{12}^{-1}
\end{array}\right) \\
\hat{\mathbf{N}}^{(i)}=\left(\begin{array}{lll}
\cos \omega_{i} & -\cos \omega_{i} & \sin \omega_{i}
\end{array}\right)^{\mathrm{T}} \quad(\text { for } i=1, \ldots, I)
\end{gathered}
$$

であり，式(31)におけるベクトルの各成分は，右CauchyGreenテンソル $\mathbf{C}$ の逆テンソルを, ベクトル・マトリク ス表示したものである.

また，式(28)(29)における仮想単純せん断ひずみ $\gamma^{(i)}$ は, 微小変形理論における式(21)と同様に, Green-Lagrangeひ ずみを用いて以下のように与えられる。

$$
\gamma^{(i)}=\left\langle\mathbf{T}^{(i)} \otimes \mathbf{N}^{(i)}\right\rangle: \mathbf{E}=\hat{\mathbf{N}}^{(i) \mathrm{T}} \hat{\mathbf{E}} \quad(\text { for } i=1, \ldots, I)
$$

ここに

$$
\hat{\mathbf{E}}^{\mathrm{T}}=\left(\begin{array}{lll}
E_{11} & E_{22} & 2 E_{12}
\end{array}\right)
$$

は, Green-Lagrangeひずみベクトルである.

さて，ひずみ空間多重せん断モデルでは，式(28)(29)に おける仮想単純せん断応力 $q^{(i)}$ を, 式(20)のような双曲 線関数で与えている. 幾何学的な非線形性に加え, 材料 的にも非線形性を考慮するのであれば，式(20)のように 各仮想単純せん断機構においてせん断強度 $q_{\mathrm{v}}$ と参照ひ ずみ $\gamma_{\mathrm{v}}$ を導入することで，ひずみ軟化の影響を考慮で きるような定式化としておくのが望ましいと考えられる。 なお，後述のゴム材料のシミュレーションに関して，双 曲線関数によるモデル化が最適かどうかという疑問は残 るが，ここでは試行的に土質動力学1)でよく用いられる 双曲線関数をそのまま採用することとした，一方，材料 的な線形性を仮定する場合には，式(20)に代えて以下の ように関係を規定すればよい。

$$
q^{(i)}=G_{\mathrm{v}} \gamma^{(i)} \quad(\text { for } i=1, \ldots, I)
$$

ここで, 式(35)におけるせん断弾性係数 $G_{\mathrm{v}}$ は, 微視的な 応力〜ひずみ関係を規定するパラメータであるが，巨視 的な物性值と明示的に対応付ける場合には, 以下のよう にすればよい，まず，仮想単純せん断機構におけるせん 断強度 $q_{\mathrm{v}}$ と参照ひずみ $\gamma_{\mathrm{v}}$ は, 巨視的な連続体として評 価した材料のせん断弾性係数 $G_{\mathrm{m}}$ と以下のように関連付 けられる334.

$$
G_{\mathrm{m}}=\frac{q_{\mathrm{v}}}{\gamma_{\mathrm{v}}} \sum_{i=1}^{I} \sin ^{2} \omega_{i} \Delta \omega
$$

図-1に仮想単純せん断機構における双曲線モデルの概念 図を示すが，この図で原点と座標 $\left(\gamma_{\mathrm{v}}, q_{\mathrm{v}}\right)$ を直線で結べ ば, 材料的に線形な場合のせん断弾性係数 $G_{\mathrm{v}}$ が求めら れる. すなわち，

$$
G_{\mathrm{v}}=q_{\mathrm{v}} / \gamma_{\mathrm{v}}
$$

と表せるので，これと式(36)より，以下のように微視的 なせん断弹性係数と巨視的なせん断弾性係数の関係性が 


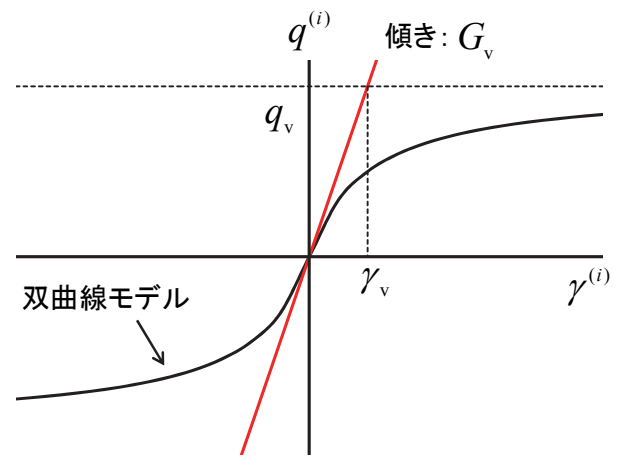

図-1 仮想単純せん断機構における双曲線モデル

導かれる。

$$
G_{\mathrm{v}}=\frac{G_{\mathrm{m}}}{\sum_{i=1}^{I} \sin ^{2} \omega_{i} \Delta \omega} \approx \frac{G_{\mathrm{m}}}{\pi / 2}
$$

（3）多重せん断機構の概念に基づく非線形弾性体（空 間表示)

前節の物質表示による非線形弹性体構成式の導出と同 様の考え方を用い，本節では多重せん断機構の概念に基 づく空間表示による新たな弾性体構成式の提案を行う. まず，現配置における空間表示によるひずみ空間多重せ ん断モデルの基本形は, 式(83)を参考にして以下のよう に与えられる.

$$
\boldsymbol{\sigma}=-p \mathbf{I}+J^{-1} \sum_{i=1}^{I} q^{(i)}\left(\left\langle\mathbf{t}^{(i)} \otimes \mathbf{n}^{(i)}\right\rangle-\gamma^{(i)} \mathbf{I}\right) \Delta \omega
$$

本稿では弾性体を対象とするため, 式(39)では土質力学 における有効応力と全応力の区別をなくすとともに，式 (83)における積分を和記号で置き換えている．なお，テ ンソル形式で表された式(39)をベクトル・マトリクス形 式に書き換えると，以下のようになる.

$$
\hat{\boldsymbol{\sigma}}=-p \hat{\mathbf{n}}^{(0)}+J^{-1} \sum_{i=1}^{I} q^{(i)}\left(\hat{\mathbf{n}}^{(i)}-\gamma^{(i)} \hat{\mathbf{n}}^{(0)}\right) \Delta \omega
$$

ここに,

$$
\begin{gathered}
\hat{\boldsymbol{\sigma}}^{\mathrm{T}}=\left(\begin{array}{lll}
\sigma_{11} & \sigma_{22} & \sigma_{12}
\end{array}\right) \\
\hat{\mathbf{n}}^{(0) \mathrm{T}}=\left(\begin{array}{lll}
1 & 1 & 0
\end{array}\right)
\end{gathered}
$$

また， $\hat{\mathbf{n}}^{(i)}$ については以下のように導出される。.まず, 基準配置における仮想単純せん断機構を表す方向べクト ル $\hat{\mathbf{N}}^{(i)}$ （式(32)）の成分を, 一度, 以下のようにテンソ ル表示に戻しておく.

$$
\left\langle\mathbf{T}^{(i)} \otimes \mathbf{N}^{(i)}\right\rangle=\left[\begin{array}{cc}
\cos \omega_{i} & \sin \omega_{i} \\
\sin \omega_{i} & -\cos \omega_{i}
\end{array}\right]
$$

次に，式(43)を現配置にpush-forward ${ }^{11)}$ することで，空間 表示で表した方向ベクトル $\hat{\mathbf{n}}^{(i)}$ のテンソル表示が以下の
ように求められる.

$$
\left\langle\mathbf{t}^{(i)} \otimes \mathbf{n}^{(i)}\right\rangle=\mathbf{F}\left\langle\mathbf{T}^{(i)} \otimes \mathbf{N}^{(i)}\right\rangle \mathbf{F}^{\mathrm{T}}=\left[\begin{array}{ll}
n_{11}^{(i)} & n_{12}^{(i)} \\
n_{21}^{(i)} & n_{22}^{(i)}
\end{array}\right]
$$

これらの成分を用いて，現配置における仮想単純せん断 機構の方向ベクトルは, 以下のように与えられる.

$$
\hat{\mathbf{n}}^{(i)}=\left(\begin{array}{lll}
n_{11}^{(i)} & n_{22}^{(i)} & n_{12}^{(i)}
\end{array}\right)^{\mathrm{T}} \quad(\text { for } i=1, \ldots, I)
$$

また，式(39)(40)における仮想単純せん断ひずみ $\gamma^{(i)}$ は, Euler-Almansiひずみを用いて以下のように与えられる.

$$
\gamma^{(i)}=\left\langle\mathbf{t}^{(i)} \otimes \mathbf{n}^{(i)}\right\rangle: \mathbf{e}=\hat{\mathbf{n}}^{(i) \mathrm{T}} \hat{\mathbf{e}} \quad(\text { for } i=1, \ldots, I)
$$

ここに

$$
\hat{\mathbf{e}}^{\mathrm{T}}=\left(\begin{array}{lll}
e_{11} & e_{22} & 2 e_{12}
\end{array}\right)
$$

は，Euler-Almansi ひずみベクトルである．なお，付録 1 の式(85)に示すように，物質表示と空間表示の違いにか かわらず，式(33)(46)で与えられる仮想単純せん断ひずみ は等しくなる.

最後に，仮想単純せん断機構における応力〜ひずみ関 係については，前節での議論（式(35)〜(38)）をそのまま 適用すればよい。

\section{4. 提案モデルを用いたシミュレーション}

\section{（1）基本特性の把握}

これまでに述べてきた弾性体の構成モデルの適用性に ついて検証するため，まず本節では，一軸圧縮引張試験 を模擬したシミュレーションを実施する。シミュレーシ ヨンの対象としたのは，既往の研究12)と同じ図-2に示す ような1要素モデル $(2 \mathrm{~cm} \times 2 \mathrm{~cm})$ であり，一軸圧縮およ び一軸引張の条件で変位制御によりシミュレーションを 行った. 本シミュレーションでは, 図-2の高さと奥行き 幅は一定で, $x$ 方向の長さのみが変化する. したがって, 体積変化，すなわち材料の圧縮性を考慮する必要がある ため, 式(38)におけるせん断岡性 $G_{\mathrm{m}}$ に加え, 式(24)等に おける体積弾性係数 $K$ を次式により算出して用いた.

$$
G_{\mathrm{m}}=\frac{E}{2(1+v)}, K=\frac{E}{3(1-2 v)}
$$

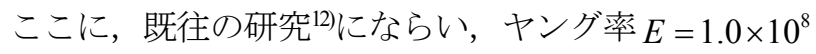
(kPa)およびポアソン比 $v=0.3$ とした.

奥行き方向に変化がないことから，シミュレーション は2次元平面ひずみ条件で実施し，材料の構成モデルは, 前章までに述べた以下の5種類とした。

Type1 : 微小変形理論に基づく一般的な線形弾性体の 構成式 (式(5)) 
Type2 : 一般的な線形弾性体を有限変形理論の物質表 示に拡張したもの（式(26)に示すSaint-Venant Kirchhoffモデル)

Type3 : 一般的な線形弾性体を有限変形理論の空間表 示に拡張したもの (式(27))

Type4 : 多重せん断機構の概念に基づく物質表示によ る非線形弾性体構成式（式(28)(29)）

Type5 : 多重せん断機構の概念に基づく空間表示によ る非線形弾性体構成式（式(39)(40)）

なお，Type4, 5では仮想単純せん断機構における微視的 な応力〜ひずみ関係を規定する必要があるが，ここでは 両者の間の材料的な線形性を仮定し, 式(35)を用いるこ ととした（幾何非線形のみ考慮）.

シミュレーションにより得られた荷重〜変位関係を図 -3に示す.まず, Type1の微小変形理論に基づく線形弾 性体では，材料的にも幾何学的にも線形性を仮定してい るため, 荷重〜変位の関係は直線で表されている. 一方, 残りの4ケースでは，材料的には線形であるものの幾何 学的な非線形性を考慮しているために，荷重〜変位関係 はType1とは異なり曲線形状となっている.

詳細に見ると，式(26)を用いたType2では，引張過程 (図中の変位が正の方向) において, Type1よりも荷重

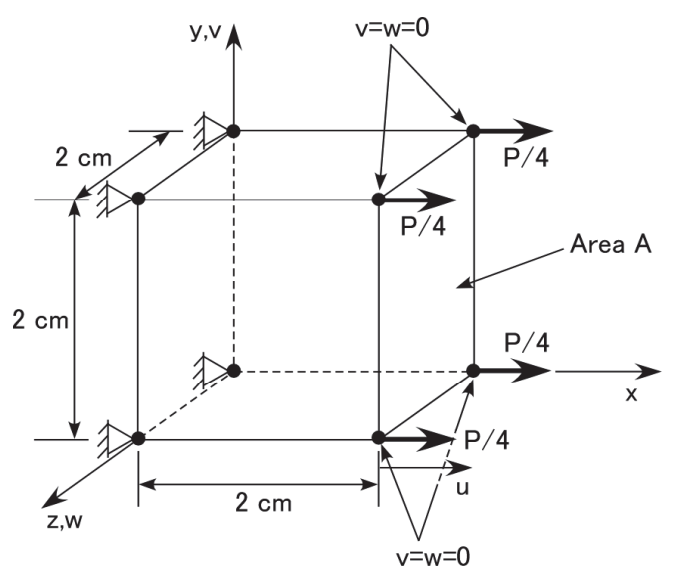

図-2 一軸圧縮引張試験の数值シミュレーションの概要

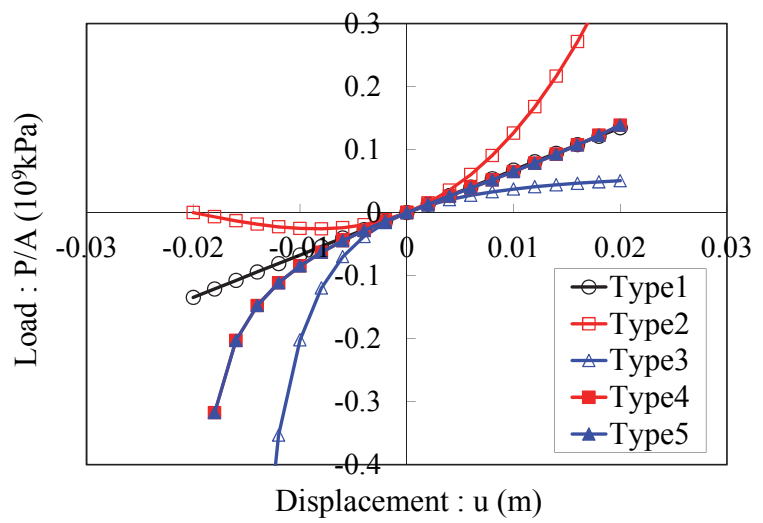

図-3
の増大が顕著である. 一方, 圧縮過程（図の変位が負の 方向）では，ある一定の圧縮変形が生じた段階から次第 に荷重が減少し，最終的にはゼロに至ることが確認でき る. 図中の変位- $0.02 \mathrm{~m} の$ 状態は，図-2からもわかるとお り，要素の体積がゼロの状態に対応する. これらの挙動 は既往の研究 ${ }^{12)}$ でも示されているが，特に土木分野で扱 う材料においてこのような傾向を示すものは見られず, 構成モデルとしては非現実的な部分を有していると考え られる.また，圧縮過程における負勾配の存在により， 荷重制御による数值シミュレーションを実施した場合, 数值解析の不安定性に関する問題が生じる可能性が高い 続いて，式(27)を用いたType3では，Type2の荷重〜変位 関係を原点対称にしたような形状になっている. 圧縮過 程に要する荷重が変位の進展とともに非常に急激に増大 するのに対し，引張過程ではすぐに荷重が頭打ちとなる 傾向にある. 本来，有限変形理論における物質表示と空 間表示は，あくまで考えの拠り所としている配置（それ ぞれ，基準配置と現配置）が異なるのみで，理論的には 等価なものである.したがって，対象としている現象が 同じであることを考えれば，物質表示と空間表示による 構成式を用いて得られた結果は，荷重〜変位関係におい ては等しくなる必要がある. 図-3におけるType2, 3を比 較すると，荷重～変位関係は大きく異なり，等価なもの とはなっていない.このような問題が生じた原因は，式 (26)(27)に示すように, 微小変形理論における線形弾性体 の剛性マトリクス（式(8)）を，単純に物質表示および 空間表示による応力〜ひずみ関係に準用したことによる ものと考えられる.

一方，本論文で提案する多重せん断機構の概念に基づ く非線形弾性体の構成式（Type4, 5) では，両者の荷重 〜変位関係が一致している. また, Type2, 3で見られた 荷重〜変位関係における両極端な傾向は抑制され，現実 的な挙動を示していることがわかる（実際の実験結果と の比較については，次節以降を参照のこと）. 加えて, Type2の圧縮過程で見られたような, 数值解析の不安定 性を誘発する負勾配も存在しない. なお， Type4, 5で荷 重〜変位関係が一致した原因としては，物質表示および 空間表示の双方において，（仮想単純せん断機構におけ る）材料関係として，式(20)もしくは式(35)を採用してい ることによると考えられる.

\section{(2) 単純せん断}

本節では，ゴム材料の単純せん断試験を対象に提案モ デルによるシミュレーションを実施し, 既往の超弾性体 モデルとの比較を行う．なお，本節以降ではゴム材料の 挙動を扱うため，非圧縮性の仮定を用いるものとする. まず，単純せん断時の変形勾配は， 


$$
\mathbf{F}=\mathbf{I}+\gamma \mathbf{e}_{1} \otimes \mathbf{e}_{2}=\left[\begin{array}{ll}
1 & \gamma \\
0 & 1
\end{array}\right]
$$

のように表せる(13)ので, 右・左Cauchy-Greenテンソルは 以下のようになる。

$$
\begin{aligned}
& \mathbf{C}=\mathbf{F}^{\mathrm{T}} \mathbf{F}=\left[\begin{array}{cc}
1 & \gamma \\
\gamma & 1+\gamma^{2}
\end{array}\right] \\
& \mathbf{b}=\mathbf{F F}^{\mathrm{T}}=\left[\begin{array}{cc}
1+\gamma^{2} & \gamma \\
\gamma & 1
\end{array}\right]
\end{aligned}
$$

ゆえに，Green-Lagrangeひずみテンソル $\mathbf{E}$ およびEulerAlmansiひずみテンソルe $\mathbf{e}$,

$$
\begin{gathered}
\mathbf{E}=\frac{1}{2}(\mathbf{C}-\mathbf{I})=\frac{1}{2}\left[\begin{array}{cc}
0 & \gamma \\
\gamma & \gamma^{2}
\end{array}\right] \\
\mathbf{e}=\frac{1}{2}\left(\mathbf{I}-\mathbf{b}^{-1}\right)=\frac{1}{2}\left[\begin{array}{cc}
0 & \gamma \\
\gamma & -\gamma^{2}
\end{array}\right]
\end{gathered}
$$

と表せるので，式(33)(46)より仮想単純せん断ひずみは以 下のように書ける.

$$
\gamma^{(i)}=-\frac{1}{2} \gamma^{2} \cos \omega_{i}+\gamma \sin \omega_{i}
$$

したがって，物質表示による第2Piola-Kirchhoff)㐫力と 空間表示によるCauchy応力は，それぞれ式(28)と式(39)に 式(54)を代入することにより求められる. 一例として Cauchy応力のせん断成分を示すと, 以下のようになる.

$$
\sigma_{12}=\sum_{i=1}^{I} q^{(i)}\left(\sin \omega_{i}-\gamma \cos \omega_{i}\right) \Delta \omega
$$

ここで，これ以降は材料非線形を考えることとし，式 (35)ではなく式(20)により $q^{(i)}$ を与えることとする.

ゴム材料の実験結果 ${ }^{14)}$ に対して提案モデルによる式 (55)を適用した結果を図-4に示寸，用いたモデルパラメ 一タは, 仮想単純せん断機構におけるせん断弾性係数 $G_{\mathrm{v}}=0.32 \mathrm{MPa}$ （巨視的なせん断弹性係数 $G_{\mathrm{m}}=0.50$ MPaに相当）およびせん断強度 $q_{\mathrm{v}}=0.28$ の 2 つである

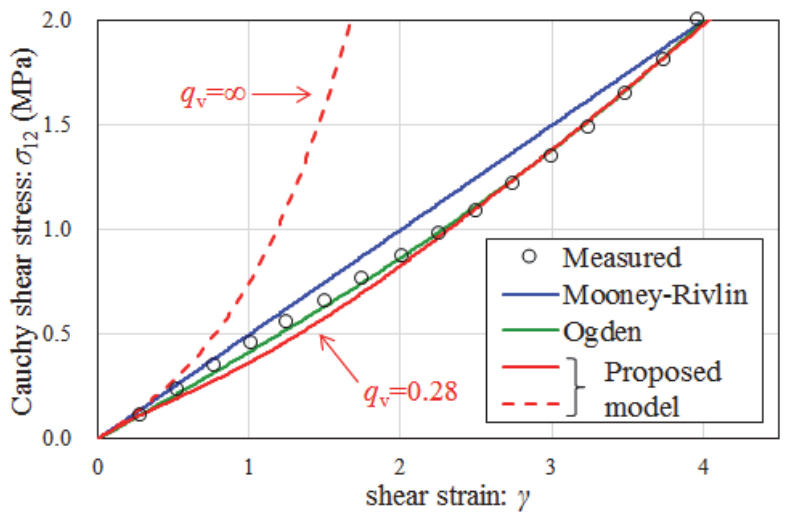

図-4 単純せん断試験に対する提案モデルの同定結果

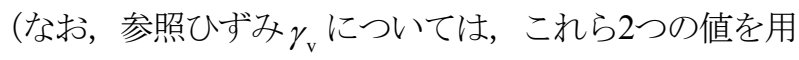
いて式(37)より自動的に決定される）。同図には，付録2 （式(88)）のMooney-Rivlin（以下, MR） モデル（ $\mu_{1}=$ $=G_{\mathrm{m}}=0.50$ ） と付録 3 （式(94)）の Ogden モデル

$\left(\mu_{1}=0.50, \mu_{2}=0.006, \mu_{3}=0.10, \alpha_{1}=2.0, \alpha_{2}=4.0\right.$, $\alpha_{3}=-2.0 ）$ の結果も示されているが，MRモデルでは パラメータが少ないという利点がある反面, $\gamma=1.5 \sim 3.5$ の広い領域でせん断応力を過大評価してい る. 一方，Ogdenモデルでは再現精度は良いものの，6つ のパラメータを同定しなければならないという久点を有 する. それに対して提案モデルでは, Ogdenモデルより もやや精度は落ちるものの，2つのパラメータで実験結 果を概ね再現できている. なお，図中の破線は，提案モ デルでせん断強度 $q_{\mathrm{v}}$ を無限大としたケース，すなわち 式(20)に代えて式(35)を用い，仮想単純せん断機構におけ る材料的な線形性を仮定した場合の結果である.この結 果より，大変形領域におけるゴム材料の挙動を正確に評 価する場合には，仮想単純せん断機構において，式(20) により材料的な非線形性も考慮する必要があると言える.

\section{（3）純せん断（圧縮領域）}

本節では，純せん断時の圧縮領域でのゴム材料の挙動 を対象に，提案モデルによるシミュレーションを行う. まず，この条件での変形勾配は，

$$
\mathbf{F}=\frac{h}{h_{0}} \mathbf{e}_{1} \otimes \mathbf{e}_{1}+\frac{h_{0}}{h} \mathbf{e}_{2} \otimes \mathbf{e}_{2}=\left[\begin{array}{cc}
\lambda & 0 \\
0 & 1 / \lambda
\end{array}\right], \lambda=\frac{h}{h_{0}}
$$

のように表せる13)ので，右・左Cauchy-Greenテンソルは 以下のようになる。

$$
\mathbf{b}=\mathbf{C}=\left[\begin{array}{cc}
\lambda^{2} & 0 \\
0 & 1 / \lambda^{2}
\end{array}\right]
$$

ゆえに，Green-Lagrangeひずみテンソル E およびEulerAlmansiひずみテンソル $\mathbf{e}$ は,

$$
\begin{aligned}
& \mathbf{E}=\frac{1}{2}(\mathbf{C}-\mathbf{I})=\frac{1}{2}\left[\begin{array}{cc}
\lambda^{2}-1 & 0 \\
0 & 1 / \lambda^{2}-1
\end{array}\right] \\
& \mathbf{e}=\frac{1}{2}\left(\mathbf{I}-\mathbf{b}^{-1}\right)=\frac{1}{2}\left[\begin{array}{cc}
1-1 / \lambda^{2} & 0 \\
0 & 1-\lambda^{2}
\end{array}\right]
\end{aligned}
$$

と表せるので，式(33)(46)より仮想単純せん断ひずみは以 下のように書ける.

$$
\gamma^{(i)}=\frac{1}{2} \cos \omega_{i}\left(\lambda^{2}-\frac{1}{\lambda^{2}}\right)
$$

したがって，第2Piola-Kirchhoffl心力とCauchy㐫力は，そ れぞれ式(28)と式(39)に式(60)を代入することにより求め られる. まず, Cauchy応力について考えると, 純せん断 
であるので一軸圧縮条件（ $\sigma_{22}=0 ）$ を考慮して,

$$
\sigma_{11}=\sum_{i=1}^{I} q^{(i)} \cos \omega_{i}\left(\lambda_{1}^{2}+\frac{1}{\lambda_{1}^{2}}\right) \Delta \omega
$$

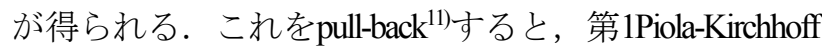
（公称）応力および第2Piola-Kirchhofff㐫力が以下のよう に求められる（なお，式(63)は式(28)より直接求めること もできる）。

$$
P_{11}=\sum_{i=1}^{I} q^{(i)} \cos \omega_{i}\left(\lambda_{1}+\frac{1}{\lambda_{1}^{3}}\right) \Delta \omega
$$

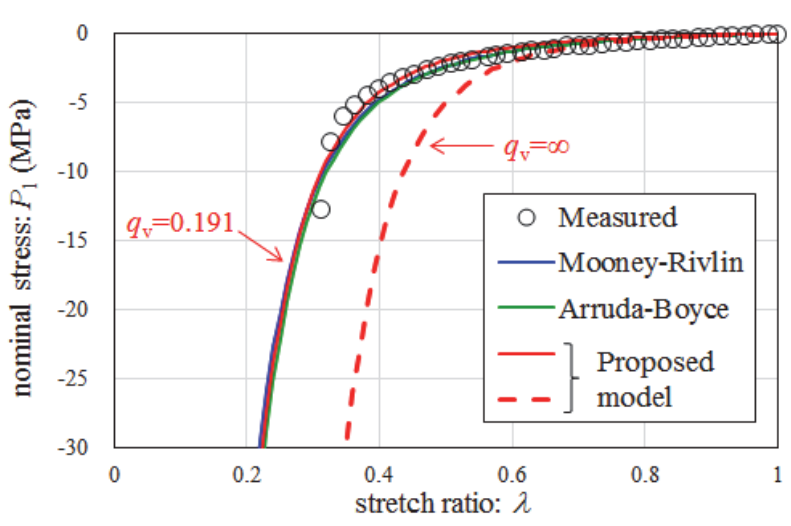

(a) gum rubber

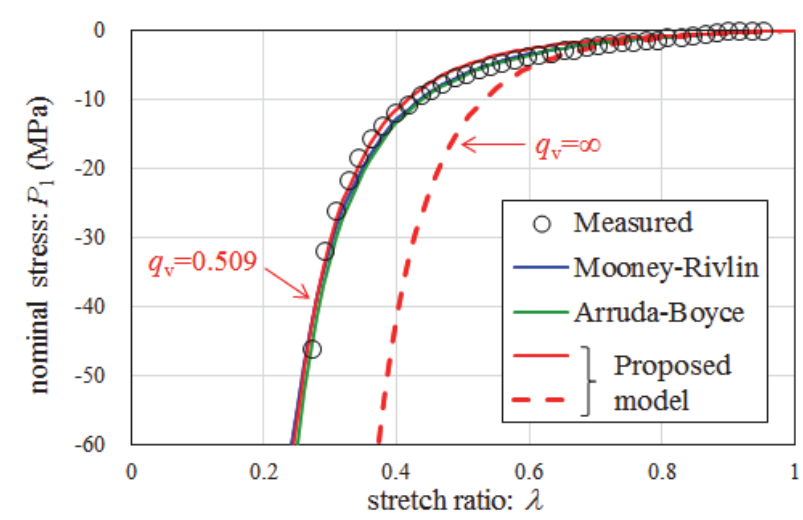

(b) neoprene rubber

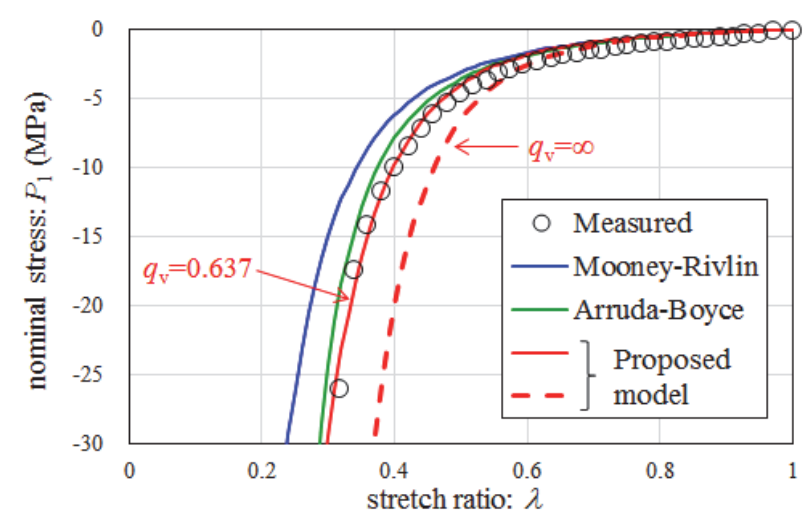

(c) silicone rubber

図-5＼cjkstart純せん断（土縮領域）に対する提案モデルの同定結果
表-1 純せん断（圧縮領域）に対するモデルパラメータ

\begin{tabular}{|c|c|c|c|c|}
\hline \multicolumn{2}{|c|}{} & gum & neoprene & silicone \\
\hline $\begin{array}{c}\text { Mooney- } \\
\text { Rivlin }\end{array}$ & $\mu_{1}$ & 0.316 & 0.854 & 0.408 \\
\hline $\begin{array}{c}\text { Amuda- } \\
\text { Boyce }\end{array}$ & $N k T$ & 0.316 & 0.854 & 0.408 \\
\cline { 2 - 5 } & $n$ & 40.0 & 40.0 & 7.9 \\
\hline $\begin{array}{c}\text { Proposed } \\
\text { model }\end{array}$ & $G_{\mathrm{m}}$ & 0.316 & 0.854 & 0.408 \\
\cline { 2 - 5 } & $q_{\mathrm{v}}$ & 0.191 & 0.509 & 0.637 \\
\hline
\end{tabular}

$$
S_{11}=\sum_{i=1}^{I} q^{(i)} \cos \omega_{i}\left(1+\frac{1}{\lambda_{1}^{4}}\right) \Delta \omega
$$

なお，前節の単純せん断の場合と同様に，ここでも式 (20)により $q^{(i)}$ を与えることとする.

ゴム材料の実験結果 ${ }^{15)}$ に対して提案モデルによる式 (62)を適用した結果を図-5に，用いたモデルパラメータ を表-1に示す，同図には，付録2（式(90)）のMRモデル と付録4（式(99)）のAmuda-Boyce（以下，AB）モデルの 結果も示してある. なお，図中の破線は，式(35)により $q^{(i)}$ を評価した場合の結果である. gum rubberと neoprene rubberに対しては，MRモデル，ABモデル，提案モデル のいずれにおいても実験結果を精度良く再現できている が， silicone rubberの場合には，MRモデルの精度はABモ デルよりも劣る結果となった。一方，提案モデルでは, $\mathrm{AB}$ モデルと同じパラメータ数ながら，わずかではある がABモデルよりも精度の良い結果が得られている。

\section{(4) 純せん断（引張領域）}

最後に，純せん断時の引張領域でのゴム挙動のシミュ レーション結果を示す，定式化は前節のとおりである.

ゴム材料の実験結果 ${ }^{10} に$ 対して提案モデルによる式 (62)を適用した結果を図-6に示す，用いたモデルパラメ ータは， $G_{\mathrm{v}}=0.38 \mathrm{MPa}$ (巨視的なせん断弾性係数 $G_{\mathrm{m}}=0.60 \mathrm{MPa}$ に相当）と $q_{\mathrm{v}}=0.20$ である. 同図には, MRモデル $\left(\mu_{1}=0.40\right)$, Ogdenモデル $\left(\mu_{1}=0.63\right.$ ， $\mu_{2}=0.0012, \mu_{3}=-0.01, \alpha_{1}=1.3, \alpha_{2}=5.0, \alpha_{3}=-2.0 ）$, $\mathrm{AB}$ モデル（ $N k T=0.30, n=26.5 ）$ の結果も併せて示さ

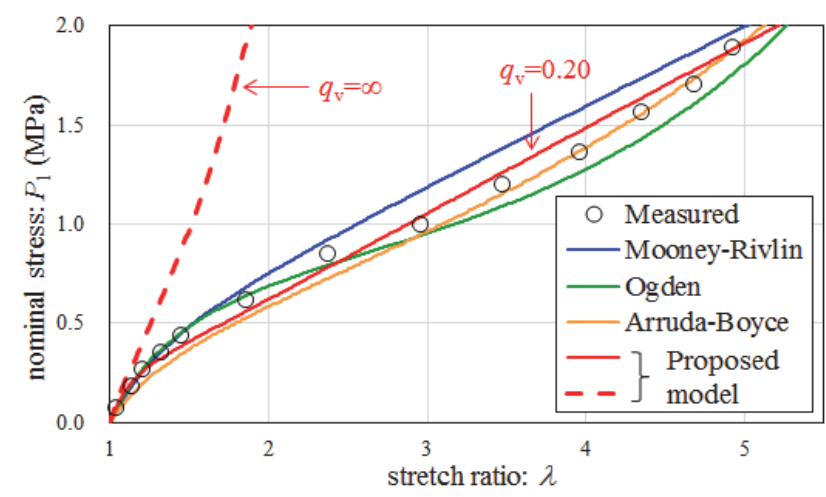

図-6 純せん断（引張領域）に対する提案モデルの同定結果 
れている. 試験結果の再現精度は, パラメータ数が最も 少ないMRモデルが一番劣り, 最も多いOgdenモデルが 一番優れている結果となった．提案モデルはABモデル と同様に, 試験結果を全ての伸長比領域で完全に再現す るまでには至っていないが，2つのモデルパラメータで 概ねの挙動は評価できているものと考えられる.

\section{5. まとめ}

本論文では，著者らが提案しているひずみ空間多重せ ん断モデルに基づき，有限変形理論に立脚した新たな非 線形弾性体の構成式を提案した. 提案モデルでは, 多重 せん断機構を構成する仮想的な各単純せん断機構（仮想 単純せん断応力と仮想単純せん断ひずみの関係）に対し て, 線形関係もしくはひずみ軟化を考慮した非線形関係 を規定している. また，大変形現象に伴う幾何学的非線 形性を考慮できるよう, 有限変形理論における物質表示 と空間表示の双方による定式化を行った。

次に, 提案モデルの妥当性を検証するため, 一軸圧縮 引張試験を模擬したシミュレーションを実施した．その 結果, 物質表示による第2Piola-Kirchhoff応力と GreenLagrangeひずみの間に直接的に線形関係を規定した非線 形弾性体の構成式では，特に圧縮過程において非現実的 な挙動（荷重～変位関係における負勾配）を示すのに対 し，提案モデルでは物質表示と空間表示のそれぞれによ り得られた荷重〜変位関係は一致しており，現実的な挙 動を示すことが確認された.

続いて, ゴム材料の引張試験（単純せん断および純せ ん断）を対象にしてシミュレーションを行った結果，モ デルパラメータとしてせん断弾性係数と仮想単純せん断 機構におけるせん断強度（もしくは参照ひずみ）の2つ を適切に調整することで, 試験結果を概ね再現できるこ とがわかった．また，提案モデルは，既存のOgdenモデ ルに代表される現象論的な超弾性体モデルと異なり，モ デルパラメータに明確な物理的意味を有している点に特 徵があると言える。

今後は，本稿での提案モデルに基づき，純せん断時の 引張領域における表現性能の向上や，三次元的なモデル の構築, さらには繰返し負荷時の応力軟化現象

(Mullins効果 ${ }^{17)}$ ) の考慮例え ${ }^{2}$, 18), 異方性超弾性体モ デル例えば, 19), 20)の構築等に取り組んでいきたい.

\section{付録1 ひずみ空間多重せん断モデルの概要}

ここでは, 砂のような粒状体の力学挙動を表現するた めに提案された，ひずみ空間多重せん断モデル3）（）概 要について述べる. このモデルでは, 任意方向の仮想単

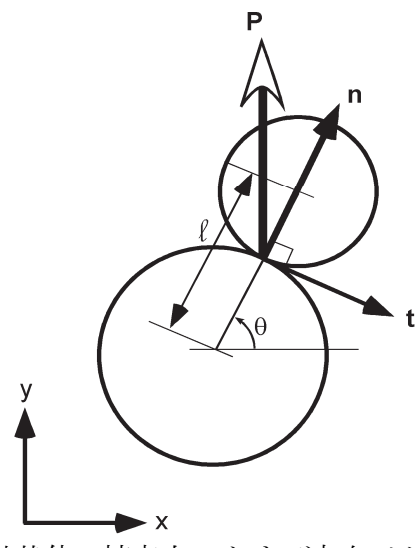

付図-1 粒状体の接点力 $\mathbf{P}$ および方向ベクトル $\mathbf{n , t}$

純せん断機構の重ね合せにより，誘導異方性を有する粒 状体の内部（微視的）構造を表現し，巨視的なひずみを 巨視的な応力に関連付ける2階のファブリックテンソル が構成される.

まず，平面内の円形粒子の集合体を考えると，接点力 $\mathbf{P}$ は, 粒子の中心を結ぶブランチ方向 $\mathbf{n}$ の成分と, こ れに直交する接線方向 $\mathbf{t}$ の成分に分解される（付図-1）.

$$
\mathbf{P}=f_{\mathrm{n}} \mathbf{n}+f_{\mathrm{t}} \mathbf{t}
$$

ここに,

$$
\begin{aligned}
& \mathbf{n}^{\mathrm{T}}=\left(\begin{array}{ll}
n_{1} & n_{2}
\end{array}\right)=\left(\begin{array}{ll}
\cos \theta & \sin \theta
\end{array}\right) \\
& \mathbf{t}^{\mathrm{T}}=\left(\begin{array}{ll}
t_{1} & t_{2}
\end{array}\right)=\left(\begin{array}{ll}
\sin \theta & -\cos \theta
\end{array}\right)
\end{aligned}
$$

連続体に対して定義される巨視的な応力は, 体積 $V$ なる代表体積要素における接点力の平均として, 枝長さ $l$ を用いて以下のとおり与えられる21,22).

$$
\boldsymbol{\sigma}^{\prime}=\frac{1}{V} \sum l\left(f_{\mathrm{n}} \mathbf{n} \otimes \mathbf{n}+f_{\mathrm{t}} \mathbf{t} \otimes \mathbf{n}\right)
$$

ここに，枝長さ $l$ は，付図-1に示すように，粒子中心を 結んだ線分の長さを表す. 式(67)は, 接点密度（単位体 積当たりの接点数) $m_{\mathrm{v}}$, 平均枝長さ $\overline{l_{0}}$, 接点分布関数 $E(\theta)$ を用い，以下のように表すことができる23).

$$
\begin{aligned}
& \boldsymbol{\sigma}^{\prime}=\frac{1}{2} m_{\mathrm{v}} \bar{l}_{0} \int_{0}^{2 \pi}\left[f_{\mathrm{n}}(\theta) E(\theta) \mathbf{I}\right. \\
& \left.+f_{\mathrm{n}}(\theta) E(\theta)\langle\mathbf{n} \otimes \mathbf{n}\rangle+f_{\mathrm{t}}(\theta) E(\theta)\langle\mathbf{t} \otimes \mathbf{n}\rangle\right] \mathrm{d} \theta
\end{aligned}
$$
ここに,

$$
\begin{gathered}
\int_{0}^{2 \pi} E(\theta) \mathrm{d} \theta=1 \\
\langle\mathbf{n} \otimes \mathbf{n}\rangle=\mathbf{n} \otimes \mathbf{n}-\mathbf{t} \otimes \mathbf{t} \\
\langle\mathbf{t} \otimes \mathbf{n}\rangle=\mathbf{t} \otimes \mathbf{n}+\mathbf{n} \otimes \mathbf{t}
\end{gathered}
$$

であり, 式(68)の導出には, 次式に示すモーメントのつ り合い式（すなわち, 応力テンソルの反刘称成分がゼロ となる条件式）24,25)を用いた。 


$$
\int_{0}^{2 \pi} f_{\mathrm{t}}(\theta) E(\theta)(\mathbf{t} \otimes \mathbf{n}-\mathbf{n} \otimes \mathbf{t}) \mathrm{d} \theta=0
$$

なお，式(68)において，接点力成分を表す $f_{\mathrm{n}}, f_{\mathrm{t}}$ は， $\theta$ 方向についての平均的な成分として定義し直している.

さらに，式(68)の右辺第2，3項は，二軸せん断と単純 せん断を表すが，両者は角度 $\pi / 4$ の相違を除けば等価 であるため, 式(68)は以下のように書き換えることがで きる.

$$
\begin{aligned}
\boldsymbol{\sigma}^{\prime}= & \frac{1}{2} m_{\mathrm{v}} \bar{l}_{0} \bar{f}_{0} \mathbf{I}+\frac{1}{2} m_{\mathrm{v}} \bar{l}_{0} \int_{0}^{2 \pi}\left[f_{\mathrm{n}}\left(\theta-\frac{\pi}{4}\right) E\left(\theta-\frac{\pi}{4}\right)\right. \\
& \left.-\bar{f}_{0} \bar{E}_{0}+f_{\mathrm{t}}(\theta) E(\theta)\right]\langle\mathbf{t} \otimes \mathbf{n}\rangle \mathrm{d} \theta
\end{aligned}
$$

ここに,

$$
\bar{f}_{0}=\int_{0}^{2 \pi} f_{\mathrm{n}}(\theta) E(\theta) \mathrm{d} \theta, \quad \bar{E}_{0}=\frac{1}{2 \pi}
$$

よって, 式(73)の各項を,

$$
p=\frac{1}{2} m_{\mathrm{v}} \bar{l}_{0} \bar{f}_{0}
$$

$q=m_{\mathrm{v}} \bar{l}_{0}\left[f_{\mathrm{n}}\left(\theta-\frac{\pi}{4}\right) E\left(\theta-\frac{\pi}{4}\right)-\bar{f}_{0} \bar{E}_{0}+f_{\mathrm{t}}(\theta) E(\theta)\right]$

を書き, さらに $\omega=2 \theta$ により変数変換を行うと, ひず み空間多重せん断モデルの基本形が以下のように与えら れる.

$$
\begin{gathered}
\boldsymbol{\sigma}^{\prime}=-p \mathbf{I}+\int_{0}^{\pi} q\langle\mathbf{t} \otimes \mathbf{n}\rangle \mathrm{d} \omega \\
\langle\mathbf{t} \otimes \mathbf{n}\rangle=\left[\begin{array}{cc}
\cos \omega & \sin \omega \\
\sin \omega & -\cos \omega
\end{array}\right]
\end{gathered}
$$

ここに，式(76)で表される仮想単純せん断応力 $q$ は, 以 下のような双曲線関数で与えるものとする.

$$
q(\gamma(\omega))=\frac{\gamma(\omega) / \gamma_{\mathrm{v}}}{1+\left|\gamma(\omega) / \gamma_{\mathrm{v}}\right|} q_{\mathrm{v}}
$$

ここに， $\gamma$ は仮想単純せん断ひずみであり，巨視的なひ ずみテンソル $\varepsilon$ を用いて,

$$
\gamma(\omega)=\langle\mathbf{t} \otimes \mathbf{n}\rangle: \boldsymbol{\varepsilon}
$$

のように与えられる. また, $q_{\mathrm{v}}, \gamma_{\mathrm{v}}$ は, 仮想単純せん断 機構におけるせん断強度と参照ひずみである.

ここで，もし材料的な線形性が仮定できる場合には， 式(79)に代えて $q=G_{\mathrm{v}} \gamma$ （ここに，定数 $G_{\mathrm{v}}$ はせん断弾性 係数）のような応力〜ひずみ関係を用いればよい，ただ し，材料的な非線形性が顕著な場合は，応力〜ひずみ関 係はこのような単純な関係で表すことができない，特に， 地盤材料のように（巨視的な）せん断ひずみの増大とと もに（巨視的な）せん断応力が一定值に収束する傾向を
示寸場合には，（微視的な）仮想単純せん断応力と仮想 単純せん断ひずみの関係においても，式 (79)のように, ひずみの進展に応じて応力〜ひずみ関係の勾配が減少し ていくようなモデル化を行う必要がある（図-1参照）。

ここまでの定式化は微小変形理論に立脚したものであ るが，大変形現象を精緻に考慮できるよう，同モデルは 有限変形理論に基づき拡張がなされている89,9). 拡張さ れたモデルでは，付図-1に示す方向ベクトル類が，物質 の変形に応じてその方向とともに大きさを変えるものと 考える. その上で, 微小変形理論で導出した式(77)が, 有限変形理論の現配置において成立すると仮定し, 空間 表示によるひずみ空間多重せん断モデルの基本形を以下 のとおり与えるものとする.

$$
\boldsymbol{\sigma}^{\prime}=-p \mathbf{I}+\int_{0}^{\pi} q\langle\mathbf{t} \otimes \mathbf{n}\rangle \mathrm{d} \omega
$$

ここに， $\sigma^{\prime}$ はCauchy（有効）応力テンソルであり，現 配置での方向ベクトル $\mathbf{n}, \mathbf{t}$ は, 基準配置でのベクトル $\mathbf{N}, \mathbf{T}$ を用いて，以下のように定義する.

$$
\mathbf{n}=\mathbf{F N}, \mathbf{t}=\mathbf{F T}
$$

ここに， $\mathbf{F}$ は変形勾配である.

ここで，方向ベクトル類が向きと大きさを変えるため, 式(81)の右辺第2項は体積変化成分を含むことになる．そ こで，圧縮性を有する超弾性体11)を参考に，等方（体積 変化）成分と偏差（体積一定）成分とに分離して定式化 を行う。すなわち, 空間表示では,

$$
\begin{aligned}
\boldsymbol{\sigma}^{\prime} & =-p \mathbf{I}+J^{-1}\left(\mathbb{N}-\frac{1}{2} \mathbf{I} \otimes \mathbf{I}\right):\left(\int_{0}^{\pi} q\langle\mathbf{t} \otimes \mathbf{n}\rangle \mathrm{d} \omega\right) \\
& =-p \mathbf{I}+J^{-1} \int_{0}^{\pi} q(\langle\mathbf{t} \otimes \mathbf{n}\rangle-\gamma \mathbf{I}) \mathrm{d} \omega
\end{aligned}
$$

となる.ここに，JはJacobian determinantである.

一方，基準配置における物質表示によるひずみ空間多 重せん断モデルの基本形は，式(83)をpull-back ${ }^{11)}$ すること により, 以下のように与えられる.

$$
\begin{aligned}
\mathbf{S}^{\prime} & =-J p \mathbf{C}^{-1}+\left(\mathbb{N}-\frac{1}{2} \mathbf{C}^{-1} \otimes \mathbf{C}\right):\left(\int_{0}^{\pi} q\langle\mathbf{T} \otimes \mathbf{N}\rangle \mathrm{d} \omega\right) \\
& =-J p \mathbf{C}^{-1}+\int_{0}^{\pi} q\left(\langle\mathbf{T} \otimes \mathbf{N}\rangle-\gamma \mathbf{C}^{-1}\right) \mathrm{d} \omega
\end{aligned}
$$

ここに, $\mathbf{S}^{\prime}$ : 第2Piola-Kirchhoff（有効）応カテンソル, C : 右Cauchy-Greenテンソルである.

なお，微小変形理論において式(80)で与えられた仮想 単純せん断ひずみ $\gamma$ は, 現配置では空間表示による方向 ベクトル類にEuler-Almansiひずみ $\mathbf{e}$ を投影することで, また基準配置では物質表示でのベクトル類にGreenLagrangeひずみE を投影することにより与えられる．両 者は，以下のとおり等価なものとなる.

$$
\gamma=\langle\mathbf{t} \otimes \mathbf{n}\rangle: \mathbf{e}=\langle\mathbf{F T} \otimes \mathbf{F N}\rangle: \mathbf{e}=\langle\mathbf{T} \otimes \mathbf{N}\rangle: \mathbf{E}
$$




\section{付録2 Mooney-Rivlinモデル}

ゴム材料に対する超弾性体モデルのうち, 最もシンプ ルな部類に属するのがMooney-Rivlinモデルである．この モデルのひずみエネルギー関数は，以下のように与えら れる13.

$$
\Psi=\frac{\mu_{1}}{2}\left(\lambda_{1}^{2}+\lambda_{2}^{2}+\lambda_{3}^{2}-3\right)-\frac{\mu_{2}}{2}\left(\lambda_{1}^{-2}+\lambda_{2}^{-2}+\lambda_{3}^{-2}-3\right)(86)
$$

ここに, $\quad \lambda_{i}(i=1 \sim 3)$ は主軸方向の伸長比, $\mu_{1}, \mu_{2}$ はモ デルパラメータである.これより, Cauchy応力は, 主軸 を規定する単位べクトル $\hat{\mathbf{n}}_{i}$ および左Cauchy-Greenテンソ ルbを用いて,

$$
\boldsymbol{\sigma}=-p \mathbf{I}+\sum_{i=1}^{3} \lambda_{i} \frac{\partial \Psi}{\partial \lambda_{i}} \hat{\mathbf{n}}_{i} \otimes \hat{\mathbf{n}}_{i}=-p \mathbf{I}+\mu_{1} \mathbf{b}+\mu_{2} \mathbf{I}
$$

\section{のように与えられる.}

単純せん断の場合は，式(87)に式(51)を代入し整理する と，以下のようなせん断応力成分が得られる.

$$
\sigma_{12}=\mu_{1} \gamma
$$

一方，純せん断の場合は，式(87)に式(57)を代入し，一 軸圧縮条件（ $\sigma_{22}=0 ）$ を考慮すると,

$$
\sigma_{11}=\mu_{1}\left(\lambda^{2}-\lambda^{-2}\right)
$$

が得られる、これをpull-back ${ }^{11)} す る と ，$ 第1Piola-Kirchhoff (公称）応力および第2Piola-Kirchhoffl心力が以下のよう に与えられる。

$$
\begin{aligned}
& P_{11}=\mu_{1}\left(\lambda-\lambda^{-3}\right) \\
& S_{11}=\mu_{1}\left(1-\lambda^{-4}\right)
\end{aligned}
$$

\section{付録3 Ogdenモデル}

Mooney-Rivlinモデルよりも高精度なゴム材料の超弾性 体モデルとして，Ogdenモデルがある．このモデルのひ ずみエネルギー関数は,

$$
\Psi=\sum_{i=1}^{3} \frac{\mu_{i}}{\alpha_{i}}\left(\lambda_{1}^{\alpha_{i}}+\lambda_{2}^{\alpha_{i}}+\lambda_{3}^{\alpha_{i}}-3\right)
$$

と表される ${ }^{13)}$. 試験結果に対する同定精度は非常に良い ものの7, パラメータの数が $6 つ\left(\mu_{i}, \alpha_{i}\right)$ と多いため, パラメータ同定には困難を伴うという久点もある。また, Ogdenモデルに代表される現象論的なモデルでは，その 材料物性值が非物理的であるとする主張もある20. 式 (92)よりCauchy忘力は, 以下のように与えられる.

$$
\begin{aligned}
\boldsymbol{\sigma} & =-p \mathbf{I}+\sum_{i=1}^{3} \lambda_{i} \frac{\partial \Psi}{\partial \lambda_{i}} \hat{\mathbf{n}}_{i} \otimes \hat{\mathbf{n}}_{i} \\
& =-p \mathbf{I}+\mu_{1} \mathbf{b}^{\alpha_{1} / 2}+\mu_{2} \mathbf{b}^{\alpha_{2} / 2}+\mu_{3} \mathbf{b}^{\alpha_{3} / 2}
\end{aligned}
$$

単純せん断の場合は，式(93)に式(51)を代入し計算した いのだが， $\alpha_{i}$ の值によっては $\mathbf{b}$ の累乗が複素数になる
可能性がある. そのため, ここでは $\alpha_{1}=2.0, \alpha_{2}=4.0$, $\alpha_{3}=-2.0$ の条件に絞り議論を進める. この場合, 以下 のようにせん断応力成分が得られる.

$$
\sigma_{12}=\left(\mu_{1}-\mu_{3}\right) \gamma+\mu_{2} \gamma\left(2+\gamma^{2}\right)
$$

一方，純せん断の場合は，式(93)に式(57)を代入し，一 軸土縮条件 $\left(\sigma_{22}=0\right)$ を考慮すると,

$$
\sigma_{11}=\sum_{i=1}^{3} \mu_{i}\left(\lambda^{\alpha_{i}}-\lambda^{-\alpha_{i}}\right)
$$

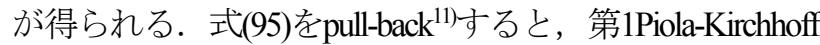
(公称) 応力および第2Piola-Kirchhoffl忘力が以下のよう に与えられる.

$$
\begin{aligned}
P_{11} & =\sum_{i=1}^{3} \mu_{i}\left\{\lambda^{\alpha_{i}-1}-\lambda^{-\left(\alpha_{i}+1\right)}\right\} \\
S_{11} & =\sum_{i=1}^{3} \mu_{i}\left\{\lambda^{\alpha_{i}-2}-\lambda^{-\left(\alpha_{i}+2\right)}\right\}
\end{aligned}
$$

\section{付録4 Amuda-Boyceモデル}

本モデルは，分子論的なアプローチに基づき提案され た超弾性体モデルで，2つの材料物性值のみでゴム材料 の非線形性を概ね表現できるとされている15). 詳細は原 著論文に譲るが，ひずみエネルギー関数は，

$$
\begin{aligned}
\Psi & =N k T\left[\frac{1}{2}\left(I_{1}-3\right)+\frac{1}{20 n}\left(I_{1}^{2}-9\right)\right. \\
& \left.+\frac{11}{1050 n^{2}}\left(I_{1}^{3}-27\right)+\frac{19}{7000 n^{3}}\left(I_{1}^{4}-81\right)+\cdots\right]
\end{aligned}
$$

で与えられ，純せん断時の伸長比に対する公称応力の理 論解は次式のように求められる（ $I_{1}:$ ひずみの第一不 変量, $L^{-1}$ : 逆Langevin関数).

$$
P_{11}=\frac{N k T}{3} \sqrt{n} L^{-1}\left(\frac{\lambda_{\text {chain }}}{\sqrt{n}}\right) \frac{\lambda-\lambda^{-3}}{\lambda_{\text {chain }}}, \lambda_{\text {chain }}=\sqrt{\frac{I_{1}}{3}}
$$

ここに, せん断弾性係数 $G_{\mathrm{m}}=N k T$ と分子鎖の重合数 $n$ はモデルパラメータであり，いずれも正の值をとる.

\section{参考文献}

1) Ishihara, K.: Soil Behaviour in Earthquake Geotech-nics, Oxford University Press, 1996.

2) Sekiguchi, H. and Ohta, H.: Induced anisotropy and time dependency in clays, 9th International Conference on Soil Mechanics and Foundation Engineering (Tokyo), pp. 306315, 1977.

3) Iai, S., Matsunaga, Y., Kameoka, T.: Strain space plasticity model for cyclic mobility, Soils and Foundations, 32(2), 115, 1992.

4) Iai,S., Tobita,T., Ozutsumi,O., Ueda,K.: Dilatancy of granular materials in a strain space multiple mechanism model, International Journal for Numerical and Analytical Methods in Geomechanics, 35(3), 360-392, 2011.

5) 上田恭平, 井合進, 飛田哲男, 小堤治：大変形（有 
限ひずみ）理論によるケーソン式混成防波堤の地震 応答解析, 土木学会論文集 A1（構造・地震工学）, 69(4), 385-395, 2013.

6) 林毅編 : 複合材料工学, 日科技連， 1971.

7) 飯塚博, 山下義裕：ゴム材料の力学特性同定と FEM 解析への利用，日本ゴム協会誌，77(9)，306-311， 2004.

8) 上田恭平 : 砂の力学モデルとしての多重せん断モデ ルの大変形解析の定式化およびその適用性に関する 研究, 京都大学博士学位論文, 2009.

9) Iai, S., Ueda, K., Tobita, T., Ozutsumi, O.: Finite strain formulation of a strain space multiple mechanism model for granular materials, International Journal for Numerical and Analytical Methods in Geomechanics, 37(9), 11891212, 2013.

10) 吉田総仁: 弾塑性力学の基礎, 共立出版株式会社, 1997.

11) Holzapfel, G.A.: Nonlinear Solid Mechanics, John Wiley \& Sons, 2000.

12) Bathe, K.J.: Finite Element Procedures, Prentice Hall.C. R, 1996.

13) Bigoni, D.: Nonlinear Solid Mechanics: Bifurcation Theory and Material Instability, Cambridge University Press, 2014.

14) Yeoh, O. H.: Characterization of elastic properties of carbon-black-filled rubber vulcanizates, Rubber Chemistry and Technology, 63(5), 792-805, 1990.

15) Arruda, E. M. and Boyce, M. C.: A three-dimensional constitutive model for the large stretch behavior of rubber elastic materials, Journal of the Mechanics and Physics of Solids, 41(2), 389-412, 1993.

16) Treloar, L. R. G.: Stress-strain data for vulcanised rubber under various types of deformation, Transactions of the Faraday Society, 40, 59-70, 1944.
17) Mullins, L.: Effect of stretching on the properties of rubber, Rubber Chemistry and Technology, 21(2), 281-300, 1948.

18) Simo, J. C.: On a fully three-dimensional finite-strain viscoelastic damage model: formulation and computation aspects, Computer Methods in Applied Mechanics and Engineering, 60(2), 153-173, 1987.

19) Lin, D. H. and Yin, F. C.: A multiaxial constitutive law for mammalian left ventricular myocardium in steady-state barium contracture or tetanus, Journal of Biomechanical Engineering, 120(4), 504-517, 1998.

20) Holzapfel, G. A., Gasser T. C., Ogden, R. W.: A new constitutive framework for arterial wall mechanics and a comparative study of material models, Journal of Elasticity and the Physical Science of Solids, 61(1), 1-48, 2000.

21) Christffersen, J., Mehrabadi, M. M., Nemat-Nasser, S.: A micromechanical description of granular material behavior, Journal of Applied Mechanics, 48, 339-344, 1981.

22) Oda, M. and Iwashita, K. (Ed.): Mechanics of Granular Materials: An Introduction, CRC Press, 1999.

23) Rothenburg, L. and Bathurst, R. J.: Analytical study of induced anisotropy in idealized granular materials, Geotechnique, 39(4), 601-614, 1989.

24) Mehrabadi, M. M., Nemat-Nasser, S., Oda, M.: On a statistical description of stress and fabric in granular materials, International Journal for Numerical and Analytical Methods in Geomechanics, 6(1), 95-108, 1982.

25) Iai, S.: Micromechanical beckground to a strain space multiple mechanism model for sand, Soild and Foundations, 33(1), 102-117, 1993.

26) Gent, A. N.: A new constitutive relation for rubber, Rubber Chemistry and Technology, 69(1), 59-61, 1996.

(2016. 6. 24 受付)

\section{FINITE STRAIN FORMULATION OF ELASTIC BODY BASED ON MULTIPLE SHEAR MECHANISM CONSIDERING GEOMETRICAL NONLINEARITY}

\section{Kyohei UEDA ans Susumu IAI}

A new formulation of elastic body is proposed based on the concept of multiple shear mechanism referring to a strain space multiple shear mechanism model for geomaterials such as sands. In the proposed model, the relationship between the virtual simple shear strain and the virtual simple shear stress in the multiple shear mechanism is assumed to be linear or nonlinear considering the effect of strain softening. In addition, the formulation is written by both the material and spatial description based on the finite strain theory in order to consider the geometrical nonlinearity due to large deformation and rotation. Comparison between experiments for rubber materials under simple or pure shear condition and its simulation results demonstrates the capability of the proposed model even though only two model parameters (i.e., shear modulus of rigidity and shear strength in the virtual simple shear mechanism) are required to be specified. 